\title{
The Pitfalls of Constructing Female Genealogy: Cultural Memory of National Socialism in Recent Family Narratives
}

\section{Dr Katherine Stone}

Email: Katie.Stone@nuim.ie

Department of German

Maynooth University

Co. Kildare

Ireland

This pre-print paper is copyright of the author, but it is free to be used for research purposes as long as it is properly attributed. Permissions for multiple reproductions should be addressed to the author. This paper is intended to circulate work that readers might not otherwise be able to access.

\section{Please cite as:}

Katherine Stone, 'The Pitfalls of Constructing Female Genealogy: Cultural Memory of National Socialism in Recent Family Narratives', in German Women's Writing in the Twenty-First Century, edited by Hester Baer and Alexandra Merley Hill (Rochester, NY: Camden House, 2015), pp. โ1 7? 
[54] Writing women's lives has always been central to the feminist project. In the 1970s confessional and autobiographical writing by women contributed to and popularized a feminist politics of self-discovery, autonomy, and solidarity. ${ }^{1}$ Questioning the relationship between language and the subject, the body and culture, female authors asserted the social and historical import of their experiences. Notably, women's writing provided insight into women's experiences of war and the Third Reich at a stage when feminist history of the period was still in its infancy. ${ }^{2}$ And now, in the twenty-first century, women writers are continuing to revisit the National Socialist past and its psychological legacy from a female perspective. The recent proliferation of autobiographical and fictional family narratives, written by women about women, suggests that there remain important stories to be told about the women who lived through the Nazi period in Germany. ${ }^{3}$ The female narratives that are typically sidelined in family and cultural memory are a pivotal concern in the memoirs Das endlose Jahr (The Endless Year, 2002) by Gisela Heidenreich, Stille Post (Chinese Whispers, 2007) by Christina von Braun, and Schweigen tut weh (The Pain of Silence, 2007) by Alexandra Senfft. These authors believe that autobiography can fill in the gaps of "official" narratives regarding women's subjective experience of history. Reflecting on the processes through which family and cultural memory are produced and gendered in the German context, they expose the exclusionary structures of cultural memory. Their works enable us to trace the social and political processes through which memory becomes inflected by gender. Recent memory narratives by women thus shed light on a question that has guided feminist interventions into memory studies: "Who wants whom to remember what and why?"4

Moreover, each author treated in this chapter reflects on what it means for her, as a mother and a daughter, to confront the family past. [55] The authors structure their narratives around the testimonial objects - diaries, photographs, and letters-through which they have gained access to the past. Integrating these objects into their writing, Heidenreich, Senfft, and von Braun unfold in front of the reader gendered forms of memory transfer. They raise important questions about how women mediate memory from one generation to the next, via various mnemonic practices such as mourning and diary-writing, but also through acts of repression. To different degrees all three imply that gender inflects not only what is remembered, but also how it is remembered. They share the suspicion that psychosomatic illnesses, such as depression and eating disorders, are symptoms of repressed or ignored female histories. They feel out the repressed emotions and traumatic reactions that are an important form of memory transfer. In these matrilineal narratives generations of women appear to be united by their feminine responses to history. Implicitly or explicitly, then, these authors suggest that there is something unique, and indeed particularly authentic, about the way that women experience the past, psychologically and corporeally. ${ }^{5}$ As a matter of fact, they largely exclude men from their reflections on memory.

As Joan Wallach Scott compellingly argues, however, a critical practice 
that relates the epistemological and social value of women's experience to their difference has a limited capacity to examine the assumptions that "excluded considerations of difference in the first place." An unreflective emphasis on women's difference may well naturalize gender roles, concealing the political and discursive operations that produce subjectivity and circumscribe agency on the basis of gender. Making reductive claims about the singular nature of women's experience of history may then reproduce the terms that have caused certain types of experience to be undervalued in cultural memory. Since certain values and attributes are codified as "masculine" and "feminine" within the cultural field of gender hierarchy, the capacity of cultural memory to represent a history that unfolds outside these imaginary parameters is restricted. This in turn limits our understanding of the agency and experience of real men and women now. In this article I consider how Heidenreich, von Braun, and Senfft negotiate the potential pitfalls of an exclusive focus on women as the subjects and objects of memory. In the first section I discuss their valuable engagements with female experiences that are all too often excluded from family and cultural memory. In the second part of this essay I turn to the various ways that Heidenreich, Senfft, and von Braun understand women as subjects and mediators of memory. Finally, I argue that the authors most successfully do justice to the specificities of female experience and memory practices, without falling back on unhelpful clichés about the otherness of femininity, when they reconstruct the mnemonic processes through which gendered identity is performed.

[56] Judith Butler argues that there is no substrate of gender identity behind expressions of gender; "identity is performatively constituted

by the very 'expressions' that are said to be its results." Building on implicit references to the iterative nature of cultural memory in authoritative social-constructivist theories of memory, we could describe cultural memory, with Judith Butler, as a "construction that regularly conceals its genesis." A certain version of the past is produced in conformity with hegemonic social values and is sustained by commemorative rituals that are performed by individuals and groups. Theories of performativity have proven instrumental to those interested in exploring the processes whereby cultural memory becomes gendered and rearticulated. ${ }^{9}$ Sabine Müller and Anja Schwarz thus encourage further consideration of how "Gedächtnis und Geschlecht sich gegenseitig hervorbringen, stützen oder aber vielleicht in Frage stellen" (memory and gender produce and sustain each other, or perhaps even challenge each other). ${ }^{10}$ In this article I suggest that memoir is uniquely positioned not just to elucidate the relationship between cultural memory and gender but also, as an important medium of cultural memory, to challenge the very gendered norms that it enshrines and perpetuates.

\section{Remembering Women}

Heidenreich, Senfft, and von Braun scrutinize aspects of female experience previously overlooked in family memory and public discussions about the Nazi past. The untold stories of mothers and grandmothers lay the groundwork for their explorations of the 
transgenerational effect of the unsaid. This endeavor is necessarily gendered in Gisela Heidenreich's best-selling Das endlose Jahr, since the author was raised by the women on her mother's side of the family. ${ }^{11}$ While working as an administrator at an SS officers' training school, Heidenreich's mother, Antonie, became pregnant with the child of a married SS Commandant. She traveled to German-occupied Norway to give birth anonymously in a Lebensborn maternity home, where she continued to be employed afterward. Across Germany and occupied territories the SS established welfare and maternity homes for unmarried, "racially valuable" women who wished to give birth in secret. Designed to raise the birth rate in the Aryan population, the Lebensborn scheme fell under the auspices of the Rasse und Siedlungshauptamt (Race and Settlement Main Office), which was charged with safeguarding the racial purity of the SS and the "Germanization" of occupied territories. ${ }^{12}$ Heidenreich struggles to discover the facts about her mother's work as an administrator in these SS institutions. Her psychological need to know the truth about her family conflicts with a filial desire to protect her aged mother from a painful confrontation with uncomfortable aspects of the past.

[57] In the appendix to her auto/biography, Heidenreich condemns the persisting lack of rigorous historical research into the Lebensborn program, a state of affairs that frustrates her desire to understand her personal history. This may be one reason why her relationship with her father, whom Heidenreich finally meets in her late teens, barely features in the narrative. The nature of his work in the SS is never in doubt. The history books cannot, however, help Heidenreich to fill in the gaps in her mother's version of her past. Nor can historical narratives, focused on objective truths, give an adequate account of the impact of history and memory on private identity formation. In her auto/biography Heidenreich constructs a narrative of lived memory, organized around female experiences that would not conventionally be deemed worth telling. As she begins associatively to piece together the memories, imagined dialogues, and fantasies that define her own memories and sense of self, she shows subjective memory to be as important as cultural memory with regard to how an individual orients herself as a gendered subject in society.

Like Heidenreich, Alexandra Senfft uses historical, literary, and family sources to produce a case study of female family memory in her book Schweigen tut weh. ${ }^{13}$ She tries to find a site of knowledge where history and subjective memory overlap, and hopes to gain insight into the lives of both her mother and her grandmother and into the way her own subjectivity has been formed in reaction to family history. An obvious springboard for Senfft's exploration of her mother's depression and alcoholism are the actions of her maternal grandfather, Hanns Ludin, Hitler's ambassador to Slovakia, who was executed in 1947. Erika, Senfft's mother, was traumatized by his arrest and hanging. Psychological issues resulting from her failure to come to terms with his death were exacerbated by unresolved questions of historical guilt. Senfft describes 
her narrative as "eine Art Tabubruch" (STW , 11; a sort of breach of taboo). Yet the taboo at stake is not the image of the honest, upstanding Hanns Ludin perpetuated by her grandmother, Erla. This had already been publicly challenged by her uncle, Malte Ludin, in his documentary film 2 oder 3 Dinge, die ich von ihm weiß (2 or 3 Things I Know about Him, 2005). Instead, Senfft breaches female family taboos: Erika's mental-health problems and Erla's political failings. Like Heidenreich, Senfft thus confronts an internalized taboo against criticizing beloved maternal figures. She notes that while men like her grandfather ensured the success of the Third Reich, so too did many women,

angefangen mit den Ehefrauen. Sie alle waren Komplizen, gemeinsam der Sache verpflichtet-und sie sind auch nach dem Krieg eine kameradschaftliche, solidarisch verbundene, eingeschworene Gemeinschaft geblieben, in der ihre Kinder und Kindeskinder aufwuchsen.

(STW, 338)

[58] [beginning with the wives. They were all complicit, dedicated to the cause-and even after the war they maintained a community, bound together in comradeship and solidarity, in which their children and grandchildren grew up.]

Senfft's narrative corroborates the findings of sociologists Gabriele Rosenthal and Margit Reiter, who have argued that a growing body of historical research about women's participation in the Third Reich has not filtered down to the level of family memory. Family confrontations with National Socialism appear to be highly gendered: "Wenden sich Kinder und Enkel dem Thema einer möglichen Täterschaft in ihrer Familie zu, dann stehen meist die Väter oder Großväter unter Verdacht" (if children and grandchildren broach the possibility of guilt in their family, then it is mostly fathers and grandfathers who come under suspicion). ${ }^{14}$ Breaking the mold and foregrounding female relatives, Senfft seeks to bring familymemory into alignment with history.

Senfft realizes that she cannot hope to understand the destructive effects of repressed knowledge and guilt while still protecting Erika and Erla from critique. Reading between the lines of Erika's letters, she unravels the psychological causes of a distress that others attributed to somatic disorders. Erika's inexplicable weight gain in the immediate postwar years was repeatedly misdiagnosed as an endocrine disorder. This diagnosis becomes a byword for her symptoms. Just as "resettlement," "fatigue duty," and "deportation" are hermeneutic loopholes for her family when dealing with the Nazi crimes, the diagnosis "hormonal issues" is a euphemism that normalizes Erika's feelings of guilt. It allows the rest of the family to continue to repress the past. Senfft hopes that by belatedlyresponding to Erika's disguised cries for help she will be able to work through her own guilt toward her mother and check the unconscious 
power of transgenerational legacies. In retrospect Senfft understands her own tomboyish behavior as a child as an attempt to draw attention to her difficulty coping with this troubled family history. She interprets the eating disorder and sleeping issues that plague her as an adult as an extension of Erika's problems. Through her writing Senfft wishes to protect her daughter from this negative inheritance.

In Stille Post Christina von Braun explicitly describes the generational continuity of psychological problems as female reactions to repressed history. ${ }^{15}$ By excavating her female family history she aims to unearth remaining family secrets and to master destructive psychological legacies such as the manic episodes of her mother, Hilde. Von Braun focuses on Hilde's ambivalent memories of her own mother, Hildegard, who died in prison in September 1944 after being arrested by the Gestapo for her involvement with a Communist resistance group. Von Braun believes that the anti-communist and anti-Jewish sentiments of the Federal Republic [59] prevented Hilde from embracing her mother's past and their shared Jewish heritage. Given von Braun's prominence as a feminist scholar and filmmaker, it is unsurprising that she styles her narrative as a corrective to the androcentrism of both cultural and family memory. In the 1920s Hildegard Margis had risen to prominence in political and business lobbies

after establishing a successful firm advising women on consumer affairs Like many early feminist activists and writers, however, she was forgotten until the advent of feminist history in the 1970s. The men in von Braun's family, diplomats, politicians, and scientists, suffered no such fate. Their lives are recorded in biographies and memoirs both published and unpublished.

Von Braun is suspicious of traditional memoirs that, "aus dem Rückblick verfasst, verführen dazu, die eigene Geschichte mit 'der Geschichte' in Einklang zu bringen. Sie treten in jedem Sinne des Wortes die Herrschaft über die Vergangenheit" (SP , 14; tempt the individual to reconcile their own story with "history" because they are composed retrospectively. They exercise mastery, quite literally, over the past). She uses the same language to discuss the genealogical research of her grandfather.

She perceives traditional autobiography and genealogy as indicating the prejudices of a patriarchal society that, passing wealth and the family name from one male generation to the next, devalues women and expunges them from history. She sees this mastery at work when she compares the published autobiography of her paternal grandfather, Magnus, with the unpublished diary of his wife, Emmy. In many instances Magnus had simply transferred Emmy's observations into his own authoritative voice and deleted nearly all traces of her in the process. It is no coincidence, von Braun muses, that her brother comes into possession of the official family memories, like the family tree, while she is charged with sorting through the diaries and photographs. She demonstrates that contributions to public memory and acts of private memory transfer belong to highly gendered traditions of authorship and inheritance. The diaries of Emmy and her mother thus form the basis of Stille Post 's 
matrilineal narrative. They allow von Braun to trace the exclusionary practices through which historical narratives are consolidated and, by implication, gendered. Favoring these female sources, she implicitly rejects the value judgments associated with generic auto/biography in which the public positioning of the writing subject, traditionally male, reflects wider social assumptions. The diaries that interest von Braun are composed in the present and without an audience in mind. They do not conform to dominant notions of what is historically relevant or to established interpretations of the past. They thus suit well her feminist genealogical project: "Ich möchte mich gern in ihre Zeit versetzen. Ich möchte etwas von dem aufspüren, was nicht in die offizielle Geschichtsschreibung eingeflossen ist" (SP , 14; I would like to [60] imagine myself in their times. I would like to ferret out some of what has not flowed into official historiography).

Like Das endlose Jahr, Stille Post blurs traditional boundaries between the apparently objective form of the biography and the more self-reflexive style of the autobiography. Von Braun's research into the lives of her relatives is presented in short, chronologically ordered sections, which are framed by fictional letters that she writes to her deceased grandmother, Hildegard Margis. In these letters von Braun considers how the events that she relates in that section either impacted Hildegard or might have been impacted by her. She then probes her own relationship to this emotional history. Although her mother and grandmothers are the apparent focus of her narrative, she thus reminds her readers that, in fact, "es ist meine Geschichte, und sie erzählt davon, wie die 'stille Post,' die sie aufgegeben haben, bei mir angekommen ist" (SP , 16; it is my story, and it recounts how I received the "Chinese whispers" that they passed on). "Stille Post" is a children's game in which messages are whispered from one person to the next, and often distorted in the process of transmission. It is known as "Chinese whispers" in the British context and as "telephone" in the United States. The authors of the widely read sociological study "Opa war kein Nazi": Nationalsozialismus und Holocaust im Familiengedächtnis ("Grandpa Wasn't a Nazi": The Holocaust in German Family Remembrance, 2002) use this game as a model to explain how memory is passed from one generation to the next. They thereby emphasize the subjective factor in the transmission of family memory. The perspective of each individual determines "welche Geschichten vom 'Dritten Reich' in den einzelnen Generationen erzählt werden, wie diese Geschichten gemeinsam im Familiengespräch verfertigt werden, welche Versatzstücke und Einzelelemente weitergegeben werden und welche nicht" (which stories about the "Third Reich" are told in different generations, how they are collectively produced in family discussions, which clichés and individual elements are passed on and which ones are not). ${ }^{16}$

For von Braun, the image of this children's game particularly conveys the unpredictable and unarticulated effects of history on the individual psyche She believes that latent messages or memories are primarily passed from mother to daughter. Von Braun attributes her academic interest in the 
women's movement and Jewish culture to the "unerledigte Aufträge" (SP , 15; unfinished assignments) that she has unconsciously taken on from Hildegard. Under the pressure of repression, she suggests, this inheritance can also take on warped forms such as her mother' depression and her own eating disorder. For von Braun, then, the history books are not the only sign that women's memories have been overlooked. This history of repression can be read "am eigenen Leib" (SP , 191; on one's own body), effectively meaning the bodies of women. Combining their reconstructions of female family history with an exploration of the [61] psychological impact of repression on generations of mothers and daughters, Heiden reich, Senfft, and von Braun's works go further than many recent examinations of women and memory. ${ }^{17}$ They direct the reader's attention to important social and psychological questions about women as subjects and agents of memory.

\section{Women Remember}

The subtitle of Stille Post is "eine andere Familiengeschichte" (a different family history). The difference that it evokes refers not merely to th stories of female relatives but to the medium in which they are communicated. At the heart of Stille Post are the intimate and embodied forms of experience

not usually acknowledged by academic history. Von Braun traces the operations of history on the female subject in order to understand better how non-canonized forms of historical knowledge are generated and imparted. She senses that women like her mother "die Geschichte' oft in einer ganz spezifischen Weise 'am eigenen Leib' erfahren und sich nur mit Verzweiflungs taten-oder eben durch Krankheiten-dagegen zu wehren vermöchten" (SP , 109; often experience "history" in a very specific manner "on the body" and can only offer resistance through acts of desperation - or even through maladies). She draws out a connection between the way that women experience history and the reasons why their stories remain untold. Von Braun argues that women have been forced to channel their feelings into non-linguistic forms because the phallogocentric order is hostile to expressions of affect. This has sent women's memories underground. In a literary extension of her decadelong academic research into women's position in phallogocentric Western culture, von Braun reads her mother's depressive episodes and fits of anger as expressions of hysteria. ${ }^{18}$ She sets up an implicit opposition between women, who are associated with the body and truth, and men, who are related to the distorting discourses of logic. This understanding of the hysteric is common among second-wave feminists influenced by Lacanian psychoanalysis and its understanding of woman's position as non-subject in the phallogocentric order. ${ }^{19}$

The imprint of history on Hilde can be seen in the bouts of depression and self-destructive behavior, to which "sie als Frau wiederholt ausgesetzt worden ist" (SP , 394; she is repeatedly exposed as a woman ). ${ }^{20}$ Von Braun seems unwilling to consider embodied reactions to history as anything other than feminine. The fact that her uncle, Hans, has obviously 
been touched by Hildegard's legacy is an exception to the rule rather than a reason for von Braun to expand her theory beyond binary notions of gender. The final pages of Stille Post extend the notion of corporeal semiotics beyond Hilde to the readers of the autobiography,who, von Braun believes, share "eine Sprache, die zu einem Teil [62] unseres Denkens, Fühlens, der Leidenschaften und damit auch unserer Geschichten wird" (SP , 405-6; a language that becomes part of our thoughts, feelings, passions, and therefore also of our history). The use of the first-person plural presupposes a common (female) identity between the author and her readers. Reifying gender as a primary constituent of historical experience, von Braun risks naturalizing the very experiences and feminine identities that she recovers from patriarchal reductionism. Her conception of female historical experience may be regarded as falsely homogenizing, as repeating the gestures of a sexual politics that justifies its operations on the basis of an assumed difference between men and women. As Marianne Hirsch and Valerie Smith have argued, "experience, as well as its recollection and transmission, is subject to gendered paradigms. But gender, like memory, must be grounded in context if it is not to remain an abstract binary structure." ${ }^{21}$ Furthermore, there is something deeply problematic about von Braun's claim that she is less interested in the content of paternal grandmother Emmy's diaries than in the language that she uses. She senses that Emmy was not truly writing in her own name, having internalized the expectations of her husband. Emmy's comportment also bears traces of male determination; she is, unlike Hilde, a paragon of female fortitude. Her behavior shows no signs of rebellion against prevailing circumstances. This explains to von Braun why Emmy seems to have had less of an impact on her sense of self than Hilde or even Hildegard Margis, whom she never met. The lasting impression of von Braun's narrative is that the most valuable female memories are those expressed in forms that cannot be subsumed by the phallogocentric logic of official cultural memory.

It would certainly be valid to ask whether this idealized conception of authentic female experience is capable of furthering our understanding of the relationship between memory and gender performance. In her eagerness to appropriate resistance as part of a female genealogy, von Braun downplays the extent to which women, as active agents, participate in existing power hierarchies and the shaping of hegemonic cultural memory. Indeed, von Braun glosses over the fact that the achievements of Hildegard Margis are silenced in family memory because Hilde is unwilling to talk about them. It will not be possible to understand fully the normative logic and repressive mechanisms of cultural memory until we are willing to acknowledge that women are not always passive or resisting participants in hegemonic culture.

In comparison to von Braun, Senfft and Heidenreich enrich our understanding of women as agents of memory by reconstructing thepractices and evolution of family memory. While Senfft depicts her grandmother as arbiter of family memory, Heidenreich critically reflects on her mother's status as custodian of family memory. Throughout her entire 
adult life her mother, Antonie, constructed various lies in order to obviate [63] the shame of being an unmarried mother. After the war Heidenreich was led to believe that her father was presumed dead when, in fact, he was living happily with his other family. Antonie had forbidden him from contacting their daughter. In this family, men, and not women, are expunged from the family tree. Outside the home Antonie denies her daughter's existence. Her former role as the mistress of an SS officer, and the daughter who resulted from this relationship, are not compatible with her postwar social identity. The lengths to which Antonie, in partnership with her mother and sister, goes in order to construct a different version of the past are an extreme manifestation of Maurice Halbwachs's recognition that "it is in society that people normally acquire their memories. It is also in society that they recall, recognize, and localize their memories." ${ }^{22}$ Only the taunts of Heidenreich's malicious uncles inject an element of historical reality into the fallacious family story perpetuated by the women. Unlike von Braun, Heidenreich does not divide notions of historical authenticity along the demarcation line of gender. Even when Heidenreich finally learns what her uncles had meant with their spiteful remarks about the "SS bastard," she is never fully convinced that her mother has told her everything about their past. Heidenreich's doubts are reinforced by a phone call from a Mr. Moser, a man who claims that his biological parents had been involved in the resistance movement within the German army. Moser believes that he was taken from his family by the SS and placed in an adoptive home by Antonie and her colleagues. Heidenreich is disturbed by Moser's speculation that her mother might be part of a conspiracy of former Lebensborn personnel who guard remaining secrets about the program. ${ }^{23}$ She nonetheless offers tentative evidence in support of this hypothesis. Heidenreich is haunted by the memory of a collection of old files hidden away in their home. She also battles with the knowledge that her mother is still in contact with Lebensborn colleagues and acquaintances, including Hitler's secretary, from her time in Allied captivity. For Heidenreich, as for Senfft, then, women are complicit in the construction of dominant and repressive historical narratives.

Moreover, she suggests that there is no simple dividing line between "official" cultural memory and "unofficial" family memory. In the case of Antonie they overlap in a particular object of repression. The exchange between different forms of memory is shown to be dynamic. It is as distorted $b$ personal investments as by cultural edicts. It follows that for Heidenreich trauma is not a constituent characteristic of women's relationship to repressed memory. Heidenreich does believe in the existence of a "law of transmission" that causes mistakes to be repeated over generations. The fact that she had, as a teenage mother, considered giving her child up for adoption makes her wonder how deeply her mother's shame had been ingrained in her own psyche. Unlike von Braun, however, Heidenreich does not suggest that this law [64] of transmission is gendered, that is to say, that it primarily passes between mothers and daughters. Looking back on the first meeting with her father when she was a teenager, Heidenreich is shocked to remember that he had reacted 
to a photograph of her then boyfriend, blue-eyed and blondehaired, with the remark "wie schön, dass du auch so ganz in unserer Art bleibst" (EJ , 278; how nice that you are sticking with our sort, too). She asks "ob ich nicht bei dieser ersten Begegnung von meinem Vater so etwas wie einem 'Auftrag' übernommen und die 'Lebensborn'-Ideologie verinnerlicht habe" (EJ , 279; whether I had taken on something like "mandate" from my father at this first meeting and internalized the "Lebensborn" ideology). For Heidenreich, a trained family therapist, psychological inheritance and historical trauma are clinical, not cultural or feminist issues. She thus feels no need to distinguish her own attempts to deal with the legacy of the past from her husband's engagement with National Socialism in his journalistic work or her son's attempts to work through the family past by writing a comedy, although these outlets for personal expression are arguably in themselves gendered.

Similarly, Alexandra Senfft's understanding of trauma is framed by empirical studies of transgenerational guilt. In this respect she is heavily influenced by her friendship and professional collaboration with Dan BarOn, whose trailblazing Legacy of Silence: Encounters with Children of the Third Reich (1989) investigated the moral and psychological legacy of guilt. The trauma that von Braun regards as part of the feminine tradition is interpreted by Senfft as the individual's reaction to a specific personal history. She interprets her own eating disorder as an attempt to gain control over her life in the face of her demanding and deeply troubled mother. One should bear this in mind when reading some of Senfft's most rhetorically striking comments about female genealogy. She memorably describes the photographs of herself, her mother Erika, and her grandmother Erla that hang in her hallway: "Irgendwann sollten wir auch ein Bild meiner Tochter hinzufügen, schließlich gehört sie zur nächsten Generation von Frauen in unserer Familie" (STW , 264; one day we should add a picture of my daughter; after all, she belongs to the next generation of women in our family). She implies that if their complicated family past is not confronted, her daughter will feel its burden more acutely than her son.

The symbolic power of such images overshadows other references in Schweigen tut weh to the impact of the troubled family past on male relatives. For example, Senfft informs her reader that Erika's brothers, too, acted out after the death of their father, clearly feeling the lack of a male figure of authority in the home. She also powerfully describes her younger brother's reaction to Erika's depression and alcoholism. On several occasions Senfft implies that women, as mothers, constitute the emotional core of the family and therefore have a particular relationship to memory. Erika's brothers stay well out of the conflict between [65] Erika and their mother and largely leave worries about her well-being to their sisters. Similarly, Senfft, and not her brother, appears to be primarily responsible for supporting Erika. For Senfft, women do not physically remember, that is to say, experience, the past differently than men. They are, however, perhaps more likely to experience it as a burden because they engage in different processes of transmitting memory. For example, 
Senfft explains the urgency of her project by stating:

Nach meiner Großmutter und meiner Mutter, die kurz hintereinander starben, bin nun ich die Nächste in der weiblichen Linie. Ich fühle mich verantwortlich, meinen Kindern meine Perspektive zu vermitteln. (STW, 16)

[I am the next in the female family line after my grandmother and my mother, who died in short succession. I feel responsible for conveying my perspective to my children.]

Women appear closely connected to history through their traditional roles as educators and caregivers. The home appears to define the parameters of female memory practice in the narratives discussed here. Certain memory practices are gendered because they are tied to women's conventional relationship to the domestic sphere. Von Braun and Senfft come into possession of their mothers' diaries and letters because it is their duty, as daughters, to clear out the homes of deceased family members. Furthermore, the act of collecting connects the three generations of women in Schweigen tut weh to repressed memories Senfft keeps her mother's letters, Erla keeps a secret box of mementos from the Nazi era, and Erika has an almost fetishistic relationship to her father's letters and possessions. According to Australian historian Tanja Luckins, collecting may form the basis of a "poetics of female memory" since, traditionally, "household and personal possessions were under the eye and care of women who, because they were less likely to control property and land, were more likely to place greater emotional investment into personal and household things." ${ }^{24}$ In the aftermath of war, Luckins continues, this investment is increased as collecting and preserving memory objects becomes integral to the process of mourning. After war, women, left behind on the home front, are then more likely than ever to be assigned the cultural task of mourning, as the matrilineal narratives of von Braun, Senfft, and Heidenreich demonstrate. As a wealth of feminist criticism has argued, however, these gendered practices are not natural or immutable. One learns and internalizes certain gender identities, performing the roles attached to them, in so far as one remembers and iterates observed behaviors and norms. Memorial practices are therefore not just gendered: they gender. ${ }^{25}$

[66]

\section{Remembering Gendered Identity}

Narrating the mental processes and physical practices whereby different individuals remember and respond to the past, the family narratives treated here tease out the ways in which gender and memory are reciprocally related in the construction of historical meaning and gendered 
identity. The authors intimate that both doing gender and doing memory are performative processes ${ }^{26}$ Like gender, as Judith Butler conceives it in Gender Trouble, cultural memory can be considered a regulatory fiction with temporal, collective, and public dimensions. The repeated performances inherent to both gender and memory sustain the social discourses of which they are effects. Relying on repetition and internalization for their normative effect, both are therefore open to resignification. The failure to repeat will expose as tenuous political constructs the historical interpretations and social norms enshrined in cultural memory. ${ }^{27}$ At its most perceptive, Christina von Braun's metaphor of the game Chinese whispers or telephone attests to the doubly subversive potential of memory practices. The hysterical female reactions to history that she admires can be read as a refusal to remember, perform, and validate hegemonic gender and historical norms. Furthermore, von Braun explicitly acknowledges that remembering is therefore an act of both recovery and creation, remarking that "über die Botschaften, die weitergegeben werden, bestimmt jeder Teilnehmer neu" (SP, 51; each participant determines anew the messages that are passé on). Individual acts of remembrance can overturn the hegemonic mandate of repression. The possibility of social transformation is therefore located in the arbitrary relation between individual and cultural memory. For von Braun this discontinuity is the key to social innovation; she believes that there is a cultural exchange between subjective and objective forms of knowledge and that "die Gesellschaft einen Gutteil ihrer Erinnerungen dieser 'stillen Post' anvertraut, vielleicht sogar die wichtigsten: all das, was verschwiegen wird, aber nicht verloren gehen darf" (SP, 15; society commits the bulk of its memories to these Chinese whispers, perhaps even the most important memories: all that is kept silent but that must not be lost). She focuses primarily on the implications of this process of exchange for cultural memory. The mechanisms of individual, family, and cultural memory are, however, also intertwined with the psychological and social processes through which individuals come to understand themselves as gendered subjects in history. After all, the regulatory fiction of binary gender identity and heterosexuality is sustained by cultural memory. Telling different stories about history, performing a different memory, or a different kind of memory, from that sanctioned by official memory culture thus also challenges the binary gender positions produced by that culture. The particular achievements of Alexandra Senfft and Gisela Heidenreich lie in the light that they shed on this dynamic.

[67] In Das endlose Jahr Heidenreich demonstrates that the gendered norms inscribed in cultural memory influence an individual's interpretation of his or her relationships and the past. Culturally ingrained ideas about motherhood, and therefore feminine identity, affect Heidenreich's personal ability to process her mother's past. When Heidenreich visits her birthplace in Oslo, she is struck by a statue of a mother with her newborn baby displayed in the Vigeland park. Heidenreich struggles to associate Antonie with this archetypal image of motherhood. She believes that her mother was anaesthetized by Nazi ideology and that her detached approach to her work has left traces in their relationship. Heidenreich thus implies that the characteristics that led her mother to make politically and 
morally troubling decisions during the Third Reich also explain her deficiency as a parent. ${ }^{28}$ In her reflections on the Lebensborn program, Heidenreich reproduces an ideology that reifies motherhood a moral identity. This ideal of motherhood explains why Heidenreich holds Antonie to a higher standard than her father. She finds it easier to understand why her father might have joined the SS, even though he is hardly the stereotypical Nazi sadist, than to imagine that her mother, or more accurately, any mother, could join the racist organization. On an intellectual level, however, Heidenreich recognizes that the gender ideals preserved in cultural memory do not measure up to the manifold experiences of real women. The circumstances of her birth make clear that the ideals she projects onto her mother are historically contingent. While Antonie was regarded as an honorable German mother within the context of the Lebensborn system, for instance, after the war she was subjected to opprobrium. The juxtaposition of three generations of mothers shows how feminine and motherly identity is renegotiated in line with changing social frameworks and in reaction to the experiences of previous generations. Antonie, for example, became involved with National Socialism as s way to avoid the sort of restrictive and exhausting life led by her mother. In turn Heidenreich's identity as mother is performed as a determined break from her mother's style of parenting.

The narrative draws to a close with a series of rhetorical questions that stage the reflexive processes through which individuals make sense of history and gendered identity over time. Heidenreich's newly wo understanding of the reciprocal and dynamic relationship between memory an identity finally allows her to find peace. Reflecting on her mother's postwar identity, Heidenreich accepts that

sie glaubt an das Lebenskostüm, in das sie geschlüpft ist, sie kann es nicht noch einmal vertauschen gegen das alte. Damals hat sie das alte Leben abgelegt wie ein gebrauchtes Kleidungsstück, das sie nun nicht mehr findet. Sie wäre nackt, wenn sie nach fünfzig Jahre das heutige Kostüm abstreifen würde. (EJ, 300-01)

[68] [she believes in the life costume that she has slipped into, she can no longer exchange it for the old one. Back then she discarded her old life like a piece of clothing that she had worn out and has now lost. She woul be naked if she were to strip off the costume that she wears nowadays.]

Heidenreich's allusions to costume evoke the performative processes through which individual memory is refashioned in conformity with evolving individual and collective parameters of remembrance, not least gender norms. For Judith Butler, identity is neither coherent nor stable but a "constituted social temporality," tenuously constructed in time and space through a stylized repetition of acts. Identity is ultimately a "performative 
accomplishment which the mundane social audience, including the actors themselves, come to believe and to perform in the mode of belief." ${ }^{29}$ Just as identity is a constantly evolving expression of individual and social value systems, memory of an event cannot be definitively separated out from the diachronic investments, norms, and external discourses in which it is implicated. In a similar manner, in the process of writing Schweigen tut weh it becomes clear to Alexandra Senfft that her mother's memories of her father shifted as her sense of self changed and with it her understanding of his impact on her life choices. As a young woman Erika strived to embody the traditional Germanic ideal of femininity that her father had exhorted her to follow in his letters from prison:

Er mahnt sie "anständig und nützlich" zu sein . . . Sie solle Sport treiben und habe als Frau "geradezu die Pflicht, hübsch zu sein"- wobei er vor allem die innere Selbstdisziplin und ein gepflegtes Äußeres meint. (STW, 163)

[He admonishes her to be "respectable and dutiful" . . . She ought to keep fit and, as woman, has "well-nigh the duty to be handsome"- by which he means, above all, inner self-discipline and a groomed appearance.]

Erika obsessively rereads her father's letters in times of crisis in order to find a source of personal orientation. She also refashions his old clothes, literally styling herself on him. These practices provide as much insight into Erika's psychology as the artifacts themselves. Reading and rereading her father's letters enacts a mnemonic process through which Erika reinforces her memories of her father. Intimately connected to a memory praxis encoded as feminine, that is, mourning, this rereading is a negotiation of family and collective history into identity. If to remember is to situate one's life in meaningful narratives that conform [69] to established social codes regarding gender, nationality, and race, then Schweigen tut weh conveys the inextricability of gendered identity formation from memory construction and recall. The letters sustain a feminine ideal with roots in the Third Reich, which is internalized by Erika as she reads and rereads them. The letters are initially Erika's primary frame of reference for interpreting her place, as a woman, in society and history. This reflects Judith Butler's contention that gender identity is never "fully self-styled, for styles have a history." ${ }^{\prime 0}$ Erika's constant desire to reinvent herself, as Eri or Erica, the softer, less Germanic variants of her name, and eventually Nora, nevertheless implies her discomfort with this ideal of femininity. Integrating excerpts from Hanns's letters into the narrative, Senfft reconstructs the manner in which Erika, in the process of remembering her father, positioned herself as gendered subject in society. "Hausfrau und Mutter will Eri sein," Senfft describes; "sie stürzt sich mit Wucht in diese Rolle und spielt sie für ihre Außenwelt perfekt" (STW , 219; Eri wants to be a housewife and mother; she throws herself 
wholeheartedly into this role, which she plays perfectly to the outside world). This language of performance characterizes Senfft's descriptions of her mother.

Just as Heidenreich senses that her mother created a false identity for herself in public in order to repress her feelings of shame, Senfft suggests that her mother disguised debilitating feelings of guilt and abnormality behind a performance of ideal femininity. Indeed, this performance was most successful when she was confronted with the left-wing friends of her husband who would have been most likely to judge her family history negatively. In an article on gender and memory in contemporary memoirs, Susanne Luhmann obliquely suggests that Erika's alcoholism and affective outbursts are a sign that she has refused gendered normalcy, "so fully does she inhabit the negative affective legacy of her father's role in the death of thousands of Slovakian Jews." ${ }^{\text {"1 }}$ In other words, her unhappy performance of the role of dutiful housewife and responsible mother expresses the traumatic knowledge of familial guilt. Erika's outbursts indicate the fundamental conflict between her wish to live up to her father's expectations and the subconscious desire to refuse their ideological foundations and to reject him for his crimes. Senfft perceptively unfolds the rituals through which her mother remembered her family past and in so doing re-membered herself as a woman in West German society. As she reassesses her image of her father, in line with changing attitudes to the Nazi past in West Germany, Erika's performance of traditional feminine identity is destabilized more and more frequently.

In comparison to von Braun, who equates trauma with femininity, Senfft shows how trauma can produce certain stylizations of gender. Laying bare these moments of trauma to the reader, without forcing [70] them into a mythologizing explanatory framework, Senfft refuses to perpetuate a family legend that has denied the effects of guilt and naturalized her mother's illness as a "hormonal disorder," as a feminine condition. She insists on the iterative nature of memory, writing: "wir alle sind Komplizen ihrer Krankheit und Komplizen beim Tradieren einer Familiensaga, die wir glauben wie Kinder ein Märchen" (STW , 289; we are all accessories to her illness and complicit in handing down a family saga. We believe in it just as children believe in fairy tales). Breaking from this script, Senfft implies, would expand the parameters of family and cultural memory and liberate the individual from the gendered norms that they perpetuate.

\section{Conclusion}

Today, as during the heyday of the feminist movement, women's memoirs remind us of the specific contours of gendered experience. What is more, Gisela Heidenreich, Christina von Braun, and Alexandra Senfft redress the selective inscription of women's experience into cultural memory. In this chapter I have argued that we can and should look to memoirs in order to understand better the relationship between gendered identity formation and cultural memory, notably their common regulative fictions 
and performative practices. Memoir is one site among many where the ideological construction of memory is orchestrated. It stages the private processes through which individuals become aware of and renegotiate the gender and conventional norms through which "history" is publicly remembered and integrated into long-term cultural memory. The memoirs analyzed here also deepen our understanding of the reciprocal relationship between acts of remembrance and identity performance. Indicating that both memory and gendered identity are constructions, they largely obviate the pitfalls of early feminist writing on women and memory that naturalized women's otherness. ${ }^{32}$ At their most innovative, the memoirs discussed in this article suggest that the repetition central to rituals of remembrance opens up possibilities for contesting the cultural script of remembrance through a reinterpretation of established historical and social norms. Moreover, since memoirs enrich and expand the archive of cultural memory, they facilitate a potential renegotiation of the hegemonic narrative that constitutes cultural memory and the mapping of gender within it. A powerful critical and political tool, memoir can stage important feminist interventions in cultural memory by reminding us, in the words of Marianne Hirsch and Valerie Smith, "that forgetting and suppressing must be contested by active remembering and that the practice and analysis of cultural memory can in itself be a form of political activism."33

\section{Notes}

1 Seminal examples of politicized autobiographical writing include Häutungen (Shedding, 1975) by Verena Stefan and Klassenliebe (Class Love, 1973) by Karin Struck. For a thoughtful discussion of many more examples see Angelika Bammer, "Feminism, Frauenliteratur, and Women's Writing of the 1970s and 1980s," in A History of Women's Writing in Germany, Austria and Switzerland, ed. Jo Catling (Cambridge: Cambridge University Press, 2000).

2 Iconic texts include the anonymous diary Eine Frau in Berlin (A Woman in Berlin, 1959); Melita Maschmann's account of her work in the League of German Girls, Fazit: Kein Rechtfertigungsversuch (1963; published in English as Account Rendered: A Dossier on my Former Self, 1964); and Marie-Thérèse Kerschbaumer's fictional documentary Der weibliche Name des Widerstands (The Female Name of Resistance, 1980). For more on this trend consult Cordula Mahr, Kriegsliteratur von Frauen? Zur Darstellung des Zweiten Weltkriegs in Autobiographien nach 1960 (Herbolzheim, Germany: Centaurus Verlag, 2006).

3 A selection of recent fictional family narratives includes Melitta Breznik's Das Umstellformat (The Reversal Format, 2002), Tanja Dückers's Himmelskörper (Heavenly Bodies, 2003), Anna Mitgutsch's Familienfest (Family Celebration, 2003), Viola Roggen kamp's Familienleben (Family Life, 2004), Sabine Schiffner's Kindbettfieber (Childbed Fever, 2005), Larissa Boehning's Lichte Stoffe (Light Materials, 2007), Katharina 
Hagena's Der Geschmack von Apfelkernen (The Taste of Apple Seeds, 2008), and Annette Pehnt's Chronik der Nähe (Chronicle of Closeness, 2012). On female family narratives, see also Valerie Heffernan's contributionto this volume.

4 Peter Burke, "History as Social Memory," in Memory: History, Cultur and the Mind, ed. Thomas Butler (New York: Blackwell, 1989), 107.

5 This is an established motif in German women's writing. In her uncompleted prose cycle Todesarten (Ways of Death), Ingeborg Bachmann related the anxiety of her female protagonists to widespread social amnesia, on the one hand, and to aspects of the self incompatible with the values of hegemonic culture, on the other. Other examples include Christa Wolf's Nachdenken über Christa T. (The Quest for Christa T., 1968) and Helma Sanders-Brahm's film Deutschland bleiche Mutter (Germany Pale Mother, 1980). For more on this see chapter 4 in Sigrid Weigel, Die Stimme der Medusa: Schreibweisen in de Gegenwartsliteratur von Frauen (Dülmen-Hiddingsel, Germany: Tende, 1987), and Claudia Öhlschläger, "Gender/Körper, Gedächtnis und Literatur," in Gedächtniskonzepte der Literaturwissenschaft: Theoretische Grundlegung und Anwendungsperspektive, ed. Astrid Erll and Ansgar Nünning (Berlin: Walter de Gruyter, 2005), 227-48. On somatic memory more generally see Aleida Assmann, Der lange Schatten der Vergangeheit: Erinnerungskultur und Geschichtspolitik (Munich: C. H. Beck, 2006), 11937.

6 Joan Wallach Scott, "The Evidence of Experience," Critical Inquiry 17 (1991): 777.

7 Judith Butler, Gender Trouble: Feminism and the Subversion of Identity, 3rd ed. (New York: Routledge Classics, 2006), 34.

[72]

8 Ibid., 190. Aleida Assmann writes, for example, that "das Gedächtnis festigt sich durch Elaboration und Wiederholung" (memory is consolidated through elaboration and repetition) in Der lange Schatten der Vergangenheit, 128. She and Jan Assmann primarily consider the iterative nature of commemorative rituals.

9 Jennifer Moos and Meike Penkwitt, eds., "Erinnern und Geschlecht," special issues, Freiburger Frauenstudien 19 (2006) and 20 (2007). See also Sabine Lucia Müller and Anja Schwarz, eds., "Iterationen: Geschlecht im kulturellen Gedächtnis," special issue, Querelles: Jahrbuch für Frauenund Geschlechterforschung 13 (2008).

10 Sabine Müller and Anja Schwarz, "Einleitung," in "Iterationen: Geschlecht im kulturellen Gedächtnis," Querelles: Jahrbuch für Frauenund Geschlecht erforschung, 18.

11 Gisela Heidenreich, Das endlose Jahr: Die langsame Entdeckung der 
eigenen Biographie-ein Lebensborn-Schicksal (Frankfurt am Main: Fischer, 2004). Further references to this work are given in the text using the abbreviation EJ.

12 The Lebensborn program is a topic of contemporary literary interest. See Karina Berger, "Children of the Lebensborn: The Search for Identity in Selected Literary Texts of the Berlin Republic," Focus on German Studies 15 (2008): 105-20.

13 Alexandra Senff, Schweigen tut weh: Eine deutsche Familiengeschichte (Berlin: List, 2008). Further references to this work are given in the text using the abbreviation STW.

14 Gabriele Rosenthal, ed., Der Holocaust im Leben von drei Generationen: Familien von Überlebenden der Shoah und von NaziTätern (Gießen: Psychosozial Verlag, 1997), 354. See also Margit Reiter, Die Generation danach: Der Nationalsozialismus im Familiengedächtnis (Innsbruck: Studienverlag, 2006).

15 Christina von Braun, Stille Post: Eine andere Familiengeschichte, 3rd ed. (Berlin: List, 2011). Further references to this work are given in the text using the abbreviation SP.

16 Harald Welzer, Sabine Moller, and Karoline Tschuggnall, "Opa war kein Nazi": Nationalsozialismus und Holocaust im Familiengedächtnis, 8th ed. (Frankfurt: Fischer, 2012), 14.

17 Feminist studies of cultural memory still frequently emphasizethe ways in which women have been excluded from cultural memory without thought for their participation in its production and transmission. See for example the introduction to The Gender of Memory: Cultures of Remembrance in Nineteenth- and Twentieth-Century Europe, ed. Sylvia Palatschek and Sylvia Schraut (Frankfurt: Campus, 2007), 7-28. The aforementioned special issues of Freiburger Frauenstudien, edited by Penkwitt and Moos, and Querelles: Jahrbuch für Frauen- und Geschlechterforschung, edited by Müller and Schwarz, represent initia but significant attempts to grasp women's participation in and influence by memory culture.

18 See Christina von Braun, "Fort da: Die Wiedergänger des kulturellen Gedächtnisses," in [Auslassungen]: Leerstellen als Movens der Kulturwissenschaft, ed. Natascha Adamowsky and Peter Matussek (Würzburg: Königshausen \& Neumann, 2004): 265-70, and Nicht Ich: Logik_Lüge_Libido (Frankfurt: Neue Kritik, 1985).

19 See Mark Micale, Approaching Hysteria: Disease and Its Interpretations (Princeton, NJ: Princeton University Press, 1995).

20 My emphasis. 
21 Marianne Hirsch and Valerie Smith, "Feminism and Cultural Memory An Introduction," special issue on "Gender and Memory," Signs 28, no. 1 (2002): 7.

22 Maurice Halbwachs, On Collective Memory, trans. Lewis Coser (Chicago: University of Chicago Press, 1992), 38.

23 On the extent to which women from the highest echelons of the Third Reich seem to have closed ranks after the war, see Margarete Dörr, Wer die Zeit nicht miterlebt hat: Frauenerfahrungen im Zweiten Weltkrieg und in den Jahren danach, 3 vols. (Frankfurt am Main: Campus, 1998), 1:23.

24 Tanja Luckins, "Collecting Women's Memories: The Australian War Memorial, the Next of Kin and Great War Soldiers' Diaries and Letters as Objects of Memory in the 1920s and 1930s," Women's History Review 19, no. 1 (2010): 31.

25 The performative element of memory is implied by the reflexive pronoun that accompanies the verb "to remember" in languages such as French ("se souvenir") or German ("sich erinnern"). As Paul Ricoeur notes, "in remembering something (se souvenant de quelque chose), one remembers oneself (on se souvient de soi)." In other words, both the past and the subject who remembers it are produced when an individual remembers. See Ricoeur, Memory, History, Forgetting, trans. Kathleen Blamey and David Pellauer (Chicago: University of Chicago Press, 2004), 96.

26 On the performative dimensions of memory see the contributions to Performing Memory in Art and Popular Culture, ed. Liedeke Plate and Anneke Smelik (New York: Routledge, 2013). See also Müller and Schwarz, "Einleitung," 11-22.

27 Butler, Gender Trouble, 190-92.

28 A similar suggestion is made in other Lebensborn narratives, such as Birgit Bauer's Im Federhaus der Zeit (2003), and in Helga Schneider's autobiography, Lass mich gehen (2004), about her estranged mother who worked as a concentration camp guard.

29 Butler, Gender Trouble, 191.

30 Ibid., 190.

31 Susanne Luhmann, "Gender and the Generations of Difficult Knowledge: Recent Responses to Familial Legacies of Nazi Perpetration," Women in German Yearbook 25 (2009): 187.

32 See the contributions to "Women and Memory," ed. Margaret Louri, Donna Stanton, and Martha Vicinus, a special issue of Michigan Quarterly Review 26, no. 1 (1987). Selma Leydesdorff reassesses this tendency in the foreword to a revised edition of Gender and Memory, ed. Selma 
Leydesdorff, Luisa Passerini, and Paul Richard Thompson (New Brunswick, NJ: Transaction, 2005).

33 Hirsch and Smith, "Feminism and Cultural Memory," 11. 